\title{
Role of $\mathrm{Gd}$ addition on machinability of $\mathrm{Al}-15 \% \mathrm{Mg}_{2} \mathrm{Si}$ in-situ composite during dry turning
}

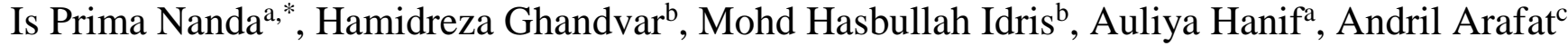 \\ ${ }^{a}$ Department of Mechanical Engineering, Universitas Andalas, Padang, 25163, Indonesia \\ ${ }^{b}$ Department of Materials, Manufacturing and Industrial Engineering, Universiti Teknologi Malaysia (UTM), 81310, Malaysia \\ ${ }^{c}$ Department of Mechanical Engineering, Universitas Negeri, Padang, 25131, Indonesia
}

Article history:

Received: 8 July 2020 / Received in revised form: 8 November 2020 / Accepted: 15 November 2020

\begin{abstract}
Recently, Al-Mg $2 \mathrm{Si}$ in-situ composites have achieved considerable attention due to their excellent physical and mechanical properties. In fact, there are some limitations of knowledge regarding the machinability characteristics of these composites - particularly when being inoculated with rare earth additions. This study in turn aimed to investigate the influence of machining parameters as well as Gd addition on the machinability of $\mathrm{Al}-15 \% \mathrm{Mg}_{2} \mathrm{Si}$ composite. To examine the effect of modifier $(1.0 \mathrm{wt} . \% \mathrm{Gd}$ ) and machining parameters (feed rate, cutting speed), microstructural evolution, surface roughness $(\mathrm{Ra})$ and cutting force $(\mathrm{Fc})$ were evaluated during dry turning. The results revealed that $\mathrm{Gd}$ addition as modifier element led to better surface roughness and higher cutting force owning to the modification of $\mathrm{Mg}_{2} \mathrm{Si}$ particle structure as well as the formation of $\mathrm{Gd}$ intermetallic compounds.
\end{abstract}

Keywords: Al-Mg $\mathrm{M}_{2} \mathrm{Si}$ composite; Rare earth; Modification; Cutting Force; Surface Roughness

\section{Introduction}

In-situ fabrication of the particulate metal matrix composites (PMMCs) during casting has some advantages such as simple production during solidification, good reinforcement particles distribution, excellent particle wetting and thermodynamic stability of particles compared to ex-situ technique $[1,2]$.

In-situ MMCs have gained considerable attention due to the convenient technical process and strong interface between reinforcement and matrix [3]. Recently, Al- $\mathrm{Mg}_{2} \mathrm{Si}$ in-situ composite as a new group of PMMCs has been introduced in automotive and aerospace industries owning to its proper physical and tribological features [4,5].

The tensile properties and machinability of hypereutectic $\mathrm{Al}-\mathrm{Mg}_{2} \mathrm{Si}$ in-situ composite are determined by the morphology and size of $\mathrm{Mg}_{2} \mathrm{Si}$ particles; therefore, controlling the structure of $\mathrm{Mg}_{2} \mathrm{Si}$ particles is deemed crucial to achieve the superb mechanical and machinability properties [6-8]. In this respect, several approaches such as rapid solidification [9], hot extrusion [10] and superheat treatment [11] and the addition of modifying elements such as Gd [12], Bi [13], Ba [14] and $\mathrm{Sb}$ [15] have been applied to control the microstructure of $\mathrm{Al}-\mathrm{Mg}_{2} \mathrm{Si}$ composite.

Gadolinium $(\mathrm{Gd})$ has a number of useful properties in alloys. $1.0 \mathrm{wt}$ \% Gd can improve the workability of iron and chromium alloys, and resistance to high temperature and

* Corresponding author. Tel.: +6285376741111; fax: +6275172566

Email: isprimananda@yahoo.com oxidation. It is also used in alloys for making magnets, electronic components and data storage disks. Its compounds are useful in magnetic resonance imaging (MRI). In addition, Gd has no known biological role, and has low toxicity [16]. $\mathrm{Gd}$ addition is also utilized to modify the structure of primary $\mathrm{Mg}_{2} \mathrm{Si}$ in $\mathrm{Al}-\mathrm{Mg}_{2} \mathrm{Si}$ composite as well as $\mathrm{Mg}-\mathrm{Si}$ alloys $[4,12]$.

Due to the existence of hard $\mathrm{Mg}_{2} \mathrm{Si}$ particles in the soft $\mathrm{Al}$ matrix, the machinability of this sort of composites is expected to be difficult especially during finishing process. The addition of alloying elements such as $\mathrm{Bi}$ is determined to be positive in solving this problem by introducing fragile chips during machining [17]. The study carried out by Yosuf et al. [18], found that the morphology of $\mathrm{Mg}_{2} \mathrm{Si}$ particles was considerably modified with the addition of 0.4 wt. $\% \mathrm{Bi}, 0.8$ wt. $\% \mathrm{Sb}$, and $0.01 \mathrm{wt}$ \% $\mathrm{Sr}$ to $\mathrm{Al}-\mathrm{Mg}_{2} \mathrm{Si}$ composite, in which the machinability of the composite was affected by increasing in cutting force and lessening the surface roughness. Similarly, Razavykia [14] claimed that the treatment of the $\mathrm{Al}-20 \% \mathrm{Mg}_{2} \mathrm{Si}-2 \mathrm{Cu}$ composite with $\mathrm{Ba}$ addition caused the modification of $\mathrm{Mg}_{2} \mathrm{Si}$ particles as well as the formation of $\mathrm{Ba}$ compound, which caused the lower cutting temperature and better surface roughness.

Similarly, it has been reported that the addition of $\mathrm{Gd}$ element to $\mathrm{Al}-15 \% \mathrm{Mg}_{2} \mathrm{Si}$ composite results in the considerable refinement/modification of composite structure and corresponding enhancement of mechanical properties of the composite compared to other RE elements [12]. For this, it is predicted that the addition of $\mathrm{Gd}$ element to $\mathrm{Al}-15 \% \mathrm{Mg}_{2} \mathrm{Si}$ composite could improve the machinability characteristics. 
The current study is targeted to examine the impact of $\mathrm{Gd}$ modifier as well as surface roughness and cutting force as machining parameters during dry turning on the machinability of $\mathrm{Al}-15 \% \mathrm{Mg}_{2} \mathrm{Si}$ in-situ composite.

\section{Materials and Methods}

Pure aluminum, magnesium in bulk form and pure silicon in the form of small blocks were utilized to fabricate Al$15 \% \mathrm{Mg}_{2} \mathrm{Si}$ composite ingot, supplied by Stanford Advanced Materials (CA 92630, USA). Table 1 depicts the composition of the elements in the fabricated composite ingot. Having been cut into small sections, the ingot of the composite was melted into a $\mathrm{SiC}$ crucible with the capacity of $5 \mathrm{~kg}$ with the help of a resistance furnace at a temperature of $760 \pm 5^{\circ} \mathrm{C}$. When the molten metal was degassed using $\mathrm{C}_{2} \mathrm{Cl}_{6}$ tablets, 1.0 wt. \% Gd was introduced to the melted composite using Al$10 \mathrm{Gd}$ rod master alloy supplied by the same supplier. The melted composite was allowed for homogenization and dissolution for approximately $5 \mathrm{~min}$ and the molten metal was agitated and casted at the temperature at $740 \pm 5^{\circ} \mathrm{C}$ into a mild steel mold to produce work-piece with a cylindrical shape.

Table 1. Composition of the elements in ingot of $\mathrm{Al}-15 \% \mathrm{Mg}_{2} \mathrm{Si}$ (wt. \%)

\begin{tabular}{lcc}
\hline & Element & Weight $\%$ \\
\hline $\mathrm{Mg}$ & 9.5 \\
$\mathrm{Si}$ & 5.5 \\
$\mathrm{Fe}$ & 0.02 \\
$\mathrm{~V}$ & 0.02 \\
$\mathrm{Cr}$ & 0.01 \\
$\mathrm{Ni}$ & 0.01 \\
$\mathrm{Ti}$ & 0.01 \\
$\mathrm{Cu}$ & 0.01 \\
$\mathrm{Mn}$ & 0.01 \\
$\mathrm{Al}$ & $\mathrm{Bal}$. \\
\hline
\end{tabular}

The composite work-piece without $\mathrm{Gd}$ addition was fabricated using the aforementioned process. The machinability experiments were carried out on $\mathrm{Al}-15 \% \mathrm{Mg}_{2} \mathrm{Si}$ (unmodified) and $\mathrm{Al}-15 \% \mathrm{Mg}_{2} \mathrm{Si}-1.0 \% \mathrm{Gd}$ (Modified). To achieve a uniform specimen with the diameter of $45 \mathrm{~mm}$ and length of $450 \mathrm{~mm}$, the specimens were rough turned and placed onto CNC lathe machine (Alpha 1350S, Harrison, UK, $8.3 \mathrm{~kW}$ power drive and maximum $6000 \mathrm{rpm}$ spindle speed).A standard tool holder was used to hold the inserts machining. Dry turning was carried out for all tests at various feed rates $(0.1,0.2,0.3 \mathrm{~mm} / \mathrm{rev})$, cutting speeds $(100,200,300 \mathrm{~m} / \mathrm{min})$ and fix depth of cut of $0.5 \mathrm{~mm}$. The chosen machining parameters were aligned with the range of the machining parameters used in the previous studies during machining of the MMCs, in which proper machining outcome has been achieved through their application [14,18].

Machinability experiment was targeted to measure the surface roughness and cutting force. Several preventive measures were taken to minimize the influence of vibration. At first, to decrease the cutting forces, the selected cutting tool owned a considerable features which reported elsewhere [14]. Then, to reduce the contact and friction between rake face and chip, the insert was selected with a chip breaker. Thus, to accomplish the turning experiments, Kennametal coated carbide insert was utilized. Metallography procedure was applied on the specimens to reveal the microstructure in which after cutting the specimens from the work-piece they were prepared by standard grinding and polishing using $\mathrm{SiC}$ sand paper and colloidal silica $(5 \mu \mathrm{m})$ respectively. Microstructure examination was conducted using optical microscope (MIDROPHOT-FXL) and SEM microscope (Philips XL40) equipped with EDS facility. Surface roughness tester (CS5000, Mitutoyo, Japan) was used to measure the surface roughness. In addition, Fc (main cutting force) was recorded during dry machining using a three-component dynamometer. Fig. 1 depicts the flowchart of the research.

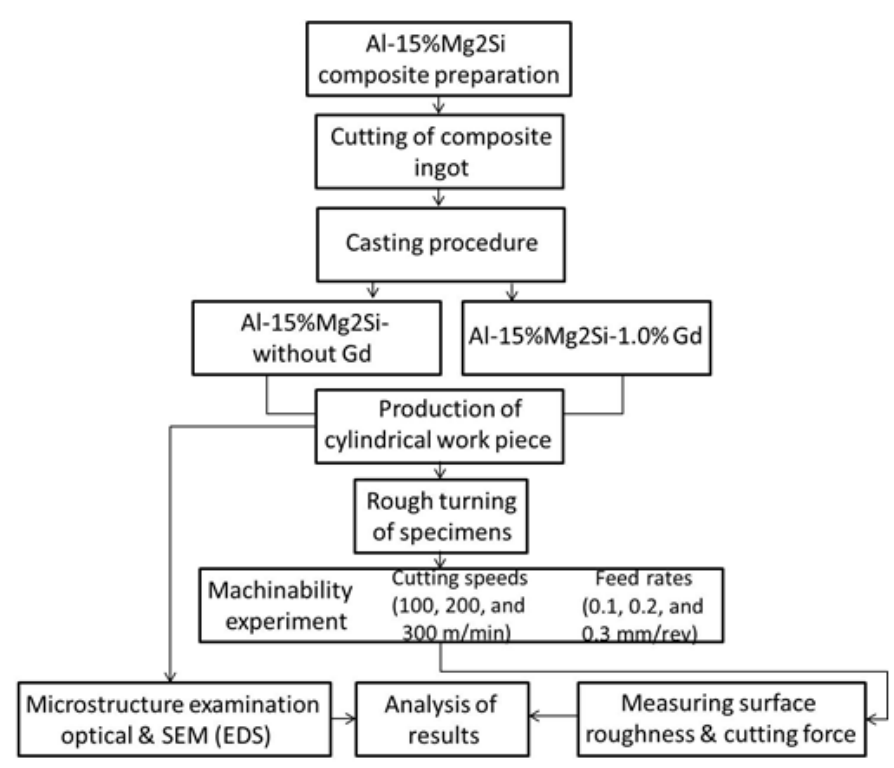

Fig. 1. Experimental procedures flow chart

\section{Results and Discussion}

\subsection{Microstructure Examination}

Fig.2 (a-d) depicts the OM/SEM images of $\mathrm{Al}-15 \% \mathrm{Mg}_{2} \mathrm{Si}$ work-piece with and without gadolinium addition. As seen in Fig. 2 (a,c), primary $\mathrm{Mg}_{2} \mathrm{Si}$ has a polyhedral morphology with hollow in its center as the indicative of unmodified primary $\mathrm{Mg}_{2} \mathrm{Si}$ morphology. Fig.2 (b,d) illustrates Al-15\% $\mathrm{Mg}_{2} \mathrm{Si}$ composite work-piece modified with 1.0 wt. \% Gd. Microstructural observation revealed that the microstructural features of primary $\mathrm{Mg}_{2} \mathrm{Si}$ crystals altered when the composite was treated with $\mathrm{Gd}$ addition, in which the particles refined the their morphology transformed to the truncated octahedral morphology in comparison to the unmodified composite. Furthermore, i- Solution image analyzer was utilized to assess the $\mathrm{Mg}_{2} \mathrm{Si}$ crystal features including density, size and aspect ratio. The features of $\mathrm{Mg}_{2} \mathrm{Si}$ particles altered considerably after the addition of Gd. The results demonstrated that the size, aspect ratio and density in the unmodified composite were $40 \mu \mathrm{m}, 1.34$ and 495 particle $/ \mathrm{mm}^{2}$ respectively. 
Nevertheless, composite modification using Gd addition led to the increase in density to 1167 particle $/ \mathrm{mm}^{2}$ and reduction in aspect ratio and size to 1.25 and $20 \mu \mathrm{m}$ respectively. This designated that the density increased by $33 \%$ and aspect ratio and size reduced by $8 \%$ and $25 \%$. These features implied the modification effect of $\mathrm{Gd}$ element on primary $\mathrm{Mg}_{2} \mathrm{Si}$ crystals in the composite.

Fig.3 (a,c) presents the BSE micrograph of the $\mathrm{Gd}$ modified work-piece, in which there were some white particles in the composite matrix near the $\mathrm{Mg}_{2} \mathrm{Si}$ particles. The resultant EDS analysis presented that these particles included Gd intermetallic compounds composing $\mathrm{Al}$, Si and $\mathrm{Gd}$. According to the atomic percentage as shown in Fig. $3 \mathrm{~b}$, the composition of intermetallic compound with irregular morphology is $\mathrm{GdAl}_{2} \mathrm{Si}_{2}$. In addition, the composition of needle-like particle is AlSiGd (Fig.3d). The modification mechanism of $\mathrm{Gd}$ addition on primary $\mathrm{Mg}_{2} \mathrm{Si}$ in $\mathrm{Al}-$ $15 \% \mathrm{Mg}_{2} \mathrm{Si}$ composite can be attributed to the nonhomogeneous nucleation, mechanism of growth restriction of $\mathrm{Mg}_{2} \mathrm{Si}$ particles by $\mathrm{Gd}$ IMCs and poisoning influence by altering the growth manner of primary $\mathrm{Mg}_{2} \mathrm{Si}$ particles by absorbing the $\mathrm{Gd}$ atoms on $\{100\}$ facets of primary $\mathrm{Mg}_{2} \mathrm{Si}$, hindering the growth [12]. It is worth mentioning that the ultimate tensile strength (UTS) value for the composite without Gd was 204.79 MPa, which increased to $224.62 \mathrm{MPa}$ with the addition of $1.0 \mathrm{wt}$. \% Gd. Furthermore, work-piece without Gd showed El\% of 2.65, which was lower than that of with 1.0 wt. $\%$ Gd (3.75).
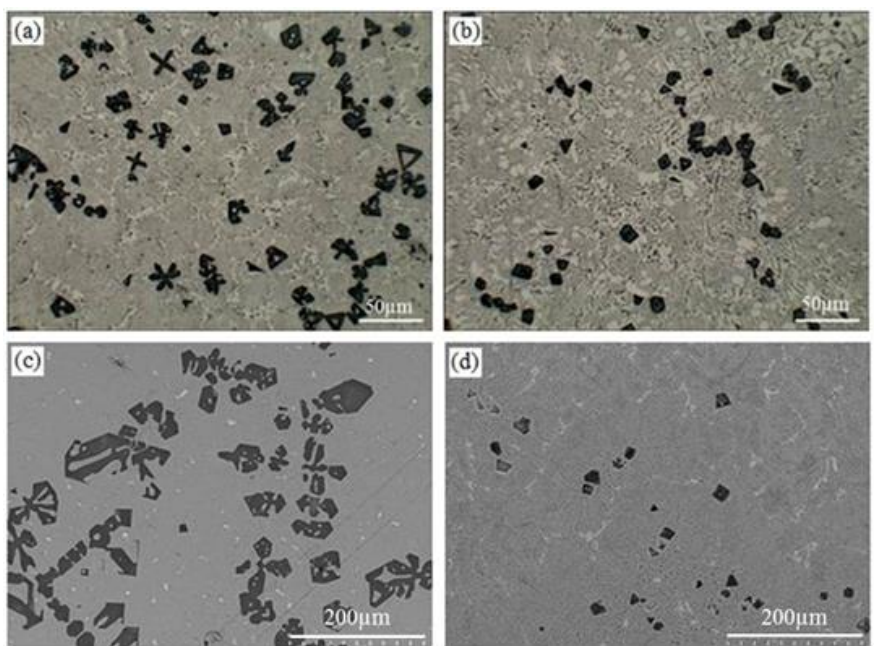

Fig. 2. OM/SEM images of $\mathrm{Al}-15 \% \mathrm{Mg}_{2} \mathrm{Si}$ composite (a and c) untreated and (b and d) treated with Gd

\subsection{Cutting Force}

Among the cutting forces, $F_{c}$ is considered as the main and prime substantial cutting force in cutting speed direction, which produces the requisite power in order to cutting. Fig. 4 depicts the amount of the cutting force under various conditions of cutting including cutting speed, constant depth of cut $(0.5 \mathrm{~mm})$ and feed rate during machining. The results indicated the increase of feed rate from $0.1 \mathrm{~mm} / \mathrm{rev}$ to 0.2 $\mathrm{mm} / \mathrm{rev}$ and the increase of the main cutting force in all conducted tests owning to the load increasing on tool tip as well as the existence of high friction between tool rake surface and chip in the zone of cutting. In addition, the increase of cutting speed from $100 \mathrm{~m} / \mathrm{min}$ to $300 \mathrm{~m} / \mathrm{min}$ led to the reduction of the main cutting force (Fig.4).
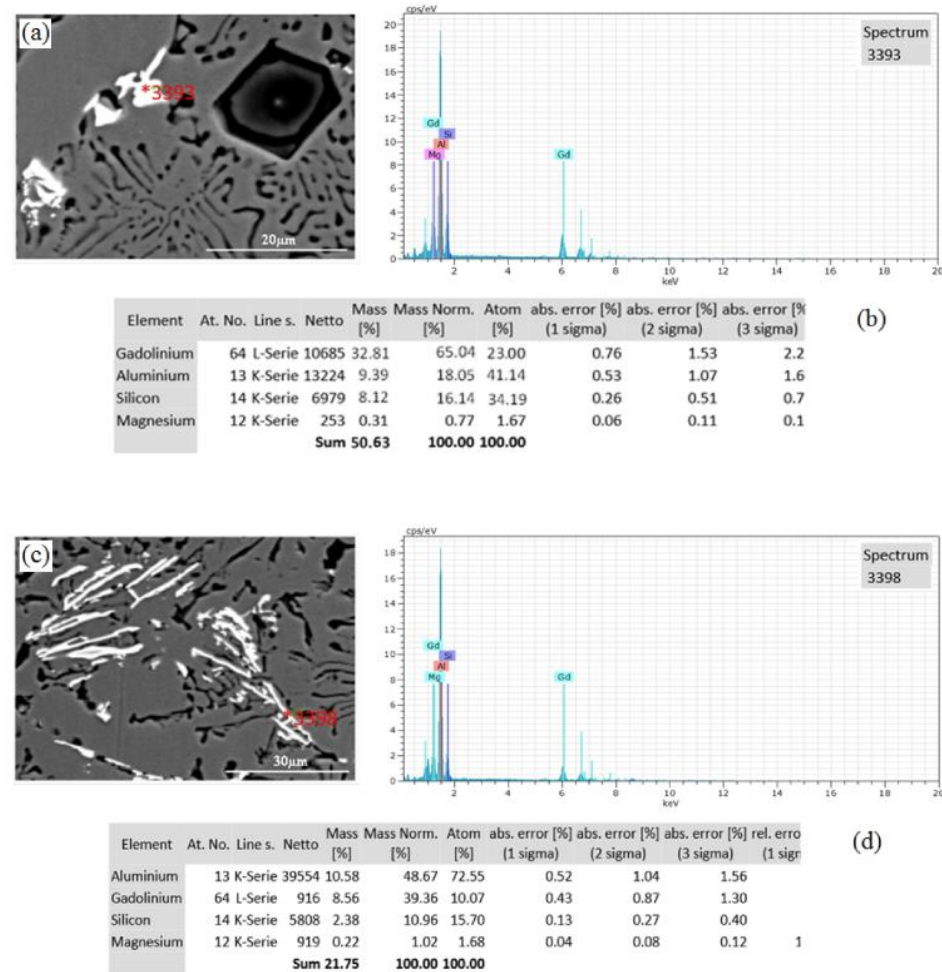

(d)

Fig. 3. (a, c) BSE micrographs of Gd IMCs (white area) and related EDS analysis

High cutting speed resulted in the increase of cutting zone temperature; as a result local material softened, which promoted the lower cutting force.

Additionally, with the increasing cutting velocity, the angle increased and then decreased the friction between chip and rake face, related to the cutting force reduction [20]. Moreover, the morphology, distribution and volume fraction of the reinforcement particles in addition to the matrix properties were are all parameters bringing some effects on the cutting properties [21]. Fig.4 also depicts the dependency of the main cutting forces on the microstructure of the workpieces in which cutting force differed based on the microstructure state. In fact, the features of $\mathrm{Mg}_{2} \mathrm{Si}$ particles, e.g. morphology, size, density and aspect ratio were significantly affected by $\mathrm{Gd}$ addition, which consequently influenced the turning process (Fig.2). The $\mathrm{Gd}$ modified work-piece interpreted higher cutting force in comparison with the unmodified composites. During the turning of the Gd modified work-piece, high cutting force could be associated to the morphology changes of $\mathrm{Mg}_{2} \mathrm{Si}$ crystals and its characteristics including shape, size and density, leading to the decrease of material tendency in the formation of built-up edge (BUE) on the face of tool rake. The alteration of the $\mathrm{Mg}_{2} \mathrm{Si}$ crystals morphology from coarse shape to fine octahedral morphology led to cutting force to be increased as a result of the high energy required to pull out or fracture the refined polygonal crystals from the composite matrix. The existence of the particle with high density improved the 
frequency of collision between cutting tool tip and particles; thus, the cutting force and tool deflection increased [22]. On the other hand, the type and reinforcement particles content in addition to strength of interfacial bonding in the interface of the matrix and particle significantly affected the peaks of stress on the cutting tool tip. Moreover, with the increase of the particle density for the plastic deformation, more energy was required of $\mathrm{Al}$. Indeed, during the turning of the $\mathrm{Al}$ composites, Al showed a plastic flow among the crystals served as an obstacle to the plastic deformation of $\mathrm{Al}$ between the crystals and push $\mathrm{Al}$ to deform between the directions with minus boundaries of particles, which subsequently resulted in the cutting force to be increased. Therefore, lowest cutting force and easier plastic deformation were generated when the particle interfaces were less or their density was low. Nevertheless, it is believed that the required cutting force for $\mathrm{Al}$ composites with small particles is less than $\mathrm{Al}$ composites with large crystal. In fact, particles with large size have large interfaces with the matrix and become the barrier for the Al to flow plastically between the particles. It subsequently leads to the increase of the cutting force [23].
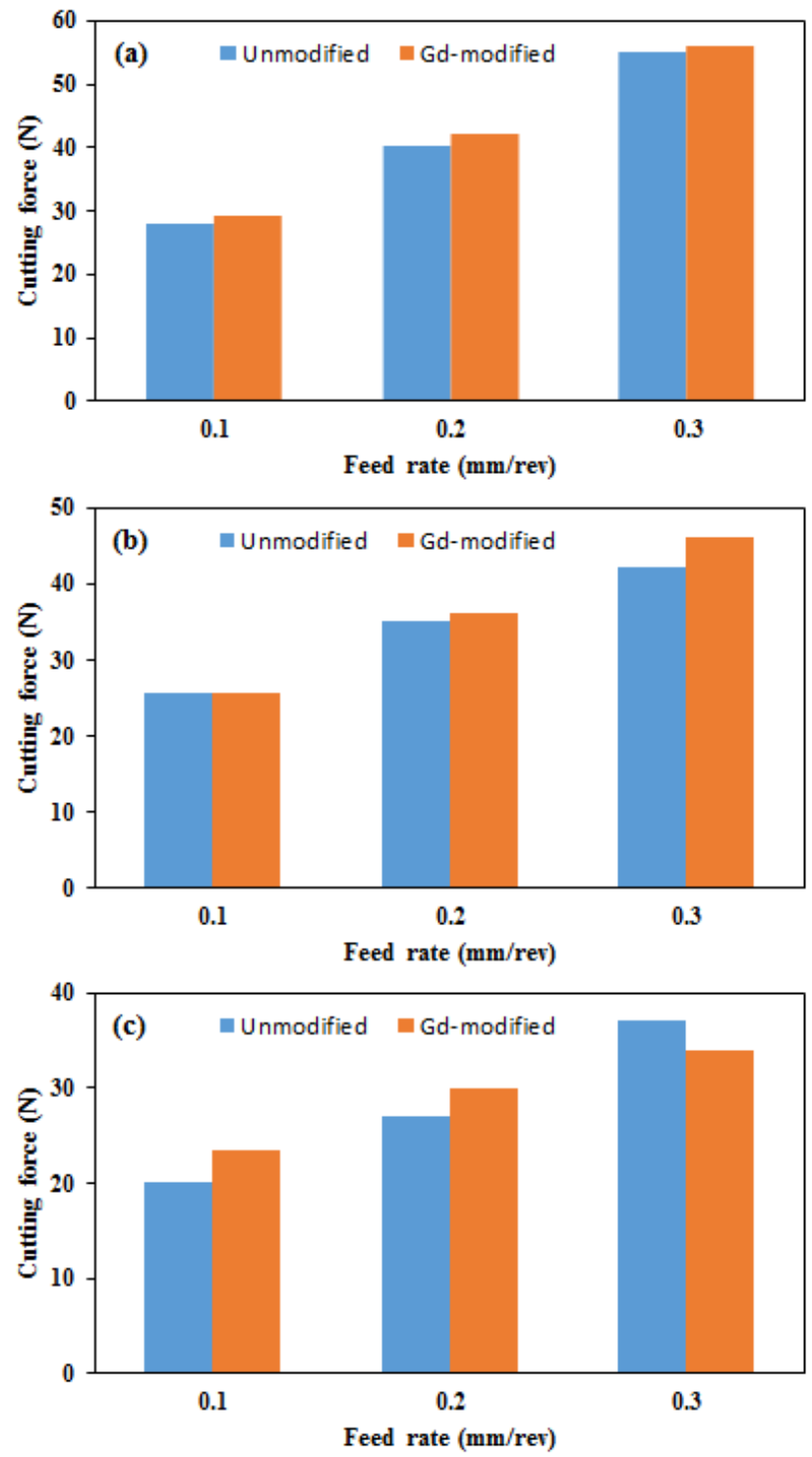

Fig. 4. Influence of feed rate and addition on cutting force (Fc) at (a) 100, (b) 200 and (c) $300 \mathrm{~m} / \mathrm{min}$ cutting speeds

\subsection{Surface Roughness}

Fig.5 presents the surface roughness of the subjected work-piece for all combinations of machining parameters. It shows that by the increase of feed rate from 0.1 to 0.3 $\mathrm{mm} / \mathrm{rev}$, the surface roughness became worse in all workpieces, which might be as the result of higher load applied on the tool. Moreover, once the feed rate value increased, the feed mark was dominated and the distance between peaks and valleys increased later on resulting in the worsening surfaces [24]. The results showed a decrease in the surface roughness values as well as the increase in the cutting speed from 100 to $300 \mathrm{~m} / \mathrm{min}$ as a result of production of BUE with shorter cycle time and smaller BUE size. Surface roughness deteriorated if the formation of BUE was like a cheap on the tool tip. Furthermore, Fig. 5 depicts the effect of Gd on the composite surface roughness. As seen for all combinations of cutting speed and feed rate, the work-piece modified with Gd addition illustrated superior surface (lower $\mathrm{R}_{\mathrm{a}}$ ) compared to unmodified one. The coarse and irregular primary $\mathrm{Mg}_{2} \mathrm{Si}$ particles were sensible to fragmentation during machining. As a result, the length of peaks and valleys was achieved in unmodified composite due to the large cut off particles; therefore, more fragmentation of such particles with cleavage fractured faces was expected to introduce a rather rough surface after machining. However, in Gd containing workpiece, with the presence of fine $\mathrm{Mg}_{2} \mathrm{Si}$ particles with a lower aspect ratio, the surface roughness was expected to be less than that of Gd-free composite. Furthermore, owning to the low solubility of $\mathrm{Gd}$ in the aluminum solid solution and high melting point compared to aluminum, the fine $\mathrm{Gd}$-rich intermetallic compounds are dispersed in the matrix (Fig.3), playing a substantial role in the composite to lessen the friction between chip and tool wear and induce a smooth surface finish (Fig.5).

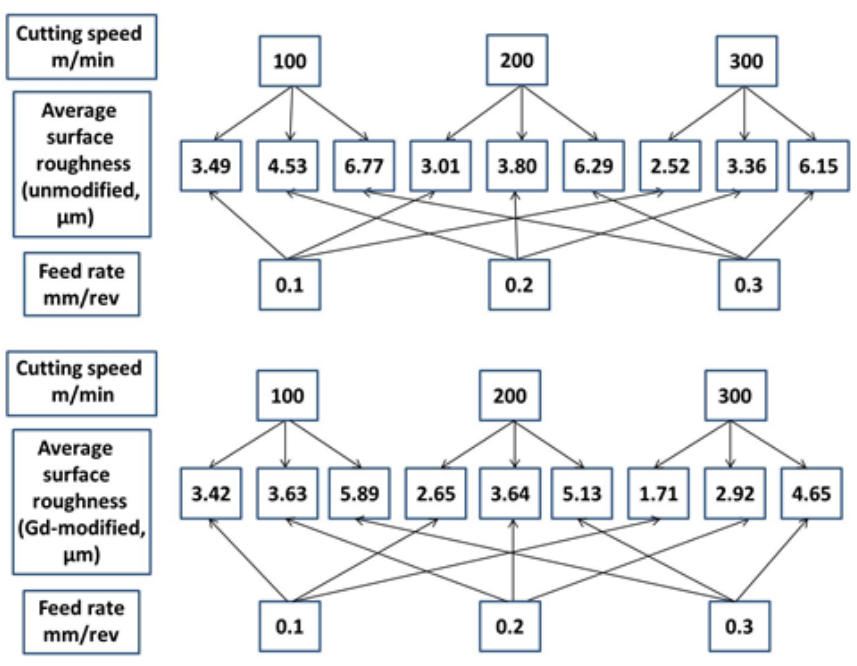

Fig. 5. Surface roughness of the untreated and Gd-treated composites

\section{Conclusion}

The machining of $\mathrm{Al}-\mathrm{Mg}_{2} \mathrm{Si}$ composite was carried out during dry turning to evaluate the effect of $\mathrm{Gd}$ element and machining parameters (constant depth of cut of $0.5 \mathrm{~mm}$, feed rates of 0.1 to $0.3 \mathrm{~mm} / \mathrm{rev}$ and cutting speeds of 100 to 300 $\mathrm{m} / \mathrm{min}$ ) on the machinability of in-situ composite. With the 
introduction of the Gd element to Al- $\mathrm{Mg}_{2} \mathrm{Si}$ composite, $\mathrm{Mg}_{2} \mathrm{Si}$ particles size, aspect ratio and density significantly altered, which in turn affected the machinability of the composite. For all combinations of machining conditions with the addition of Gd the $\mathrm{Mg}_{2} \mathrm{Si}$ particles, density increased, thus leading to the increase of cutting force. The formation of BUE and workpiece material affected the surface roughness. Gd addition led to the formation of smaller $\mathrm{Mg}_{2} \mathrm{Si}$ particles in the fabricated composite, which caused the lower surface roughness to be achieved. Moreover, in the cutting zone, surface roughness, friction and temperature decreased due to the formation of new Gd IMCs.

\section{Acknowledgements}

The authors would like to place their sincere thanks for financial and technical support under research grant of the Department of Mechanical Engineering Faculty of Engineering 2019 Universitas Andalas. The authors would also like to acknowledge Department of Material, Manufacturing and Industry, School of Mechanical Engineering at Universiti Teknologi Malaysia. Finally, the authors wish to acknowledge Department of Mechanical Engineering, Faculty of Engineering, Universitas Negeri Padang, and all staff involved for the valuable supports provided during this work.

\section{References}

1. Q.D. Qin, Y.G. Zhao, W. Zhou, P.J. Cong, Effect of phosphorus on microstructure and growth manner of primary $\mathrm{Mg}_{2}$ Si crystal in $\mathrm{Mg}_{2} \mathrm{Si} / \mathrm{Al}$ composite, Mater. Sci. Eng: A. 447 (2007) 186-191.

2. L. Y. Pan, H. Q. Yu, Sh. Jiang, L.Y. Wang, Min Zuo, The structural evolution of Al-6Y-2P master alloy and its influence on the refinement of $\mathrm{Mg}_{2} \mathrm{Si}$ phase in $\mathrm{Mg}_{2} \mathrm{Si} / \mathrm{Al}$ composites, Mater. Sci. Forum. 913 (2018) 490497.

3. Y.G. Zhao, Q.D. Qin, W. Zhou, Y.H. Liang, Microstructure of the Cemodified in situ $\mathrm{Mg}_{2} \mathrm{Si} / \mathrm{Al}-\mathrm{Si}-\mathrm{Cu}$ composite, J. Alloys. Compd. 389 (2005) L1-L4

4. Y. Sun, C. Li, Y. Liu, L. Yu, H. Li, Intermetallic phase evolution and strengthening effect in $\mathrm{Al}-\mathrm{Mg}_{2} \mathrm{Si}$ alloys with different $\mathrm{Cu} / \mathrm{Ni}$ ratios, Mater. Let. 215 (2018) 254-258.

5. X. Tong, D. Zhang, K. Wang, J. Lin, Y. Liu, Z. Shi, Y. Li, J. Lin, C. Wen, Microstructure and mechanical properties of high-pressureassisted solidification of in situ $\mathrm{Al}-\mathrm{Mg}_{2} \mathrm{Si}$ composites, Mater. Sci. Eng: A. 733 (2018) 9-15.

6. Y.M. Kim, S.W. Choi, Y. Kim, C.S. Kang, S-K. Hong, Influence of the Precipitation of Secondary Phase on the Thermal Diffusivity Change of Al-Mg 2 Si Alloys, Appl. Sci. 8 (2018) 2039.

7. W. Jiang, X. Xiaofeng, Zh. Yuguang, Z. Wang, Ch, Wu, D, Pan, Zh, Meng, Effect of the addition of Sr modifier in different conditions on microstructure and mechanical properties of T6 treated Al- $\mathrm{Mg}_{2} \mathrm{Si}$ in-situ composite, Mater. Sci. Eng: A. 721 (2018) 263-273.
8. B. W. Huang, Q. D. Qin, D. H. Zhang, Y. J. Wu, X. D. Su, Microstructure and mechanical properties of dissimilar joints of Al$\mathrm{Mg}_{2} \mathrm{Si}$ and 5052 aluminum alloy by friction stir welding, J. Mater. Eng. Perform. 27 (2018) 1898-1907.

9. X. Tong, D. Zhang, K. Wang, J. Lin, Y. Liu, Z.Shi, Y. Li, J. Lin, C. Wen, Microstructure and mechanical properties of high-pressure-assisted solidification of in situ Al-Mg 2 Si composites, Mater. Sci. Eng: A. 733 (2018) 9-15.

10. H. Ghandvar, M. H. Idris, N. Ahmad, Effect of hot extrusion on microstructural evolution and tensile properties of $\mathrm{Al}-15 \% \mathrm{Mg}_{2} \mathrm{Si}-x \mathrm{Gd}$ insitu composites, J. Alloys. Compd. 751 (2018) 370-390.

11. Q.D. Qin, Y.G. Zhao, Y.H. Liang, W. Zhou, Effects of melt superheating treatment on microstructure of $\mathrm{Mg}_{2} \mathrm{Si} / \mathrm{Al}-\mathrm{Si}-\mathrm{Cu}$ composite, J. Alloys. Compd. 399 (2005) 106-109.

12. H. Ghandvar, M. H. Idris, N. Ahmad, M. Emamy, Effect of gadolinium addition on microstructural evolution and solidification characteristics of Al-15\% Mg 2 Si in-situ composite, Mater. Charact. 135 (2018) 57-70.

13. S. Farahany, H. Ghandvar, N. A. Nordin, A. Ourdjini, M. H. Idris, Effect of primary and eutectic $\mathrm{Mg}_{2} \mathrm{Si}$ crystal modifications on the mechanical properties and sliding wear behavior of an $\mathrm{Al}-2 \mathrm{OMg}_{2} \mathrm{Si}-2 \mathrm{Cu}-x \mathrm{Bi}$ composite, J. Mater. Sci. Technol. 32 (2016) 1083-1097.

14. A. Razavykia, H. Ghandvar, M. H. Idris, Effect of barium (Ba) addition on dry turning of a commercial $\mathrm{Al}-2 \mathrm{OMg}_{2} \mathrm{Si}-2 \mathrm{Cu}$ metal matrix composite, Int. J. Innov. Eng. Technol. 10 (2018) 25-31.

15. S. Farahany, H. Ghandvar, N. A. Nordin, A. Ourdjini, Microstructure characterization, mechanical, and tribological properties of slow-cooled $\mathrm{Sb}$-treated Al-20Mg2Si-Cu in-situ composites, J. Mater. Eng. Perform. 26 (2017) 1685-1700.

16. Y. Lingying, H. Jilong, T. Changping, Z. Xinming, D. Yunlai, L. Zhaoyang, Z. Zhile, Modification of $\mathrm{Mg}_{2} \mathrm{Si}$ in $\mathrm{Mg}-\mathrm{Si}$ alloys with gadolinium, Mater. Charact. 79 (2013) $1-6$.

17. Y.T. Pei, J.Th.M. De Hosson, Functionally graded materials produced by laser cladding, Acta. Mater. 48 (2000) 2617- 2624.

18. N.M. Yusof, A. Razavykia, S. Farahany, A. Esmaeilzadeh, Effect of modifier elements on machinability of $\mathrm{Al}-20 \% \mathrm{Mg}_{2} \mathrm{Si}$ metal matrix composite during dry turning, Machining science and technol. 20 (2016) 460-474.

19. N.A, Abukhshim, P.T, Mativenga, M.A, Sheikh, Heat generation and temperature prediction in metal cutting: A review and implications for high speed machining, Int. J. Mach. Tool. Manu. 46 (2006) 782-800.

20. Y. Sahin, M. Kok, H. Celik, Tool wear and surface roughness of $\mathrm{Al}_{2} \mathrm{O}_{3}$ particle-reinforced aluminium alloy composites, J. Mater. Process. Tech. 128 (2002) 280-291.

21. J. Grum, M. Kisin, Influence of microstructure on surface integrity in turning-part II: the influence of a microstructure of the workpiece material on cutting forces, Int. J. Mach. Tool. Manu. 43 (2003) 15451551.

22. S. Kannan, H.A, Kishawy, Surface characteristics of machined aluminium metal matrix composites, Int. J. Mach. Tool. Manu. 46 (2006) 2017-2025.

23. K. Palanikumar, N. Muthukrishnan, K.S. Hariprasad, Surface roughness parameters optimization in machining A356/SiC/20p metal matrix composites by PCD tool using response surface methodology and desirability function, Mach, Sci, Technol. 12 (2008) 529-545. 